\title{
Microbial Compositions and Enzymes of a Forest Ecosystem in Alabama: Initial Response to Thinning and Burning Management Selections
}

\author{
Fritz A. Ntoko', Terrence G. Gardner ${ }^{2}$, Zachary N. Senwo ${ }^{1 *}$, Veronica Acosta-Martinez ${ }^{3}$ \\ ${ }^{1}$ Department of Biological and Environmental Sciences, College of Agricultural, Life and Natural Sciences, Alabama A \& M \\ University, Normal, AL, USA \\ ${ }^{2}$ Department of Soil Science, North Carolina State University, Raleigh, NC, USA \\ ${ }^{3}$ USDA-ARS, Cropping Systems Research Laboratory, Wind Erosion and Water Conservation Unit, Lubbock, TX, USA \\ Email: fritzenburg@gmail.com, tggarnde@ncsu.edu, *zachary.senwo@aamu.edu, \\ veronica.acosta-martinez@ars.usda.gov
}

How to cite this paper: Ntoko, F. A., Gardner, T. G., Senwo, Z. N., \& Acosta-Martinez, V. (2018). Microbial Compositions and Enzymes of a Forest Ecosystem in Alabama: Initial Response to Thinning and Burning Management Selections. Open Journal of Forestry, 8, 328-343.

https://doi.org/10.4236/ojf.2018.83021

Received: April 1, 2018

Accepted: July 15, 2018

Published: July 18, 2018

Copyright $\odot 2018$ by authors and Scientific Research Publishing Inc. This work is licensed under the Creative Commons Attribution International License (CC BY 4.0).

http://creativecommons.org/licenses/by/4.0/

(c) (i) Open Access

\begin{abstract}
Prescribed burning and tree thinning are commonly used restoration practices for US forests management to increase forest productivity and enhance plant and animal diversity. The impact of these practices in Alabama's Bankhead National Forest (BNF) to soil microbial components and overall forest soil health are unknown. We hypothesized that microbial assemblages and enzyme activities are continuously changing in forest ecosystems especially due to management selections. Therefore, the objective of this study was to assess changes in microbial community compositions (fungal vs bacterial populations) via fatty acid methyl ester (FAME) profiling and several enzyme activities ( $\beta$-glucosaminidase, acid phosphatase, arylsulfatase, $\beta$-glucosidase, xylanase, laccase, and manganese peroxidase) critical to soil organic matter (SOM) dynamics and biogeochemical cycling. In this forest, heavily-thinned plots without burning or less frequent burning treatments seemed to provide more favorable conditions (higher $\mathrm{pH}$ and lower $\mathrm{C}: \mathrm{N}$ ratios) for $\mathrm{C}$ and $\mathrm{N} \mathrm{mi-}$ neralization. This may explain a slight increase (by $12 \%$ ) detected in fungi:bacteria (F:B) ratio in the heavily-thinned plots relative to the control. Thinned (lightly and heavily) plots showed greater ligninolytic (laccase and $\mathrm{MnP}$ ) activities and lower $\beta$-glucosidase and $\beta$-glucosaminidase activities compared to the no-thinned plots probably due to increase depositions of woody recalcitrant $\mathrm{C}$ materials. We observed significant but negative correla-
\end{abstract}


tions between the ligninolytic laccase and manganese peroxidase (Lac and $\mathrm{MnP})$ enzymes respectively, with $\mathrm{MBC}\left(-0.45^{*}\right.$ and $-0.68^{* *}$ respectively) and MBN $\left(-0.43^{*}\right.$ and $-0.65^{\star *}$ respectively). Prescribed burning treatment reduced microbial biomass $\mathrm{C}$ and $\mathrm{N}$ of the 9 -yr burned plot/lightly thinned plotsprobably due to depletion of labile $\mathrm{C}$ sources with the high temperatures, leaving mostly recalcitrant $C$ sources as available soil substrates. Gram-positive bacteria (i15:0, a15:0, i17:0, and a17:0), actinomycetes (10-Me17:0, 10-Me18:0),

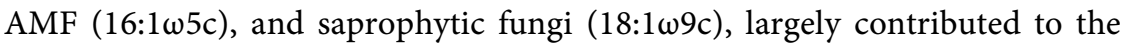
microbial compositions. This study bridges knowledge gaps in our understanding of microbial community compositions and enzyme-mediated processes in repeatedly burned and thinned forest ecosystems.

\section{Keywords}

Forest Soil Health, Forest Ecosystems, Microbial Compositions, Enzyme Metabolisms, Thinning and Burning

\section{Introduction}

Prescribed burning and tree thinning are commonly used restoration practices for US forests management (Boerner et al., 2000; McRae et al., 2001; Agee \& Skinner, 2005; Nobles et al., 2009). These practices have been implemented in Alabama's Bankhead National Forest (BNF), to mitigate the negative impacts of pest and disease outbreaks (Nobles et al., 2009), reduce fuel loads and accumulated ground flora on forest floors to promote growth of new forage and plants (Converse et al., 2006), increase forest productivity and enhance plant and animal diversity (Ganzlin et al., 2016). Forest productivities, plant nutrient concentrations, microbial richness, enzymatic metabolisms are possibly altered after fire events and forest thinning practices (Wic-Baena et al., 2013; Akburak \& Makineci, 2015). Studies have reported an increase (Bååth et al., 1995; Klopatek et al., 1988) and/or decrease (Baar et al., 1999; Grogan et al., 2000), in short-lived bacteria proliferation and little or no increase in soil fungi (Jonsson et al., 1999) due to prescribed burning and/or tree thinning. However, a comprehensive study of the combination of these practices will shed more light into how these practices can impact the microbial component and the whole forest ecosystem health and functioning.

Microbial communities are known to mediate nutrient cycling and facilitate nutrient distributions (Wagner \& Wolf, 1998; Wander, 2004) through their enzymatic machinery. Enzyme metabolic reactions are key to carbon (C), nitrogen $(\mathrm{N})$, phosphorus $(\mathrm{P})$, and sulfur $(\mathrm{S})$ mineralization in soils. Their decrease in forest treatments (post burn and/ or thin) have been associated with decreased microbial biomass (Pietikåinen \& Fritze, 1995; Andersson et al., 2004). The decrease may also result from changes in substrate availability resulting from altered quantity and quality of soil organic matter (Bandick \& Dick, 1999; Tian et 
al., 2010). Prescribed burning and thinning practices will change not only the highly efficient nutrient-conserving mechanisms that characterize a forest but also soil organic matter (SOM) cycling patterns and enzymatic metabolisms within the ecosystem (Garcia-Montiel et al., 2000). We hypothesized that microbial compositions, metabolic capacities, and functions are continuously changing in forest ecosystems. Therefore, the objectives of this study were to assess changes in microbial community compositions and several enzyme activities ( $\beta$-glucosaminidase, acid phosphatase, arylsulfatase, $\beta$-glucosidase, xylanase, laccase, and manganese peroxidase) associated with $\mathrm{C}, \mathrm{N}, \mathrm{P}$, and $\mathrm{S}$ cycling in a forest ecosystem as affected by different combinations of prescribed burning and tree thinning. Trends found should be considered in future management decisions to preserve biodiversity and functioning of forest ecosystems.

\section{Materials and Methods}

\subsection{Study Site}

The William B. Bankhead National Forest (Figure 1) situated in the Southern Cumberland Plateau of the Southern Appalachian Mountains, extends through Lawrence, Winston, and Franklin counties $\left(34^{\circ} 30^{\prime} \mathrm{N}, 87^{\circ} 30^{\prime} \mathrm{W}\right)$ in Alabama. Its climate is classified as humid subtropical, has an average annual temperature of $18^{\circ} \mathrm{C}$, covers over 180,000 acres of land, with abundant swift streams, limestone bluffs, and waterfalls. It is also home to Alabama's only National and Scenic Sipsey Fork River and several different genera of wildlife. The soils are classified as Typic Hapludults of the Sipsey (fine-loamy, siliceous, semi-active, thermic Typic Hapludults) series in the USDA soil classifications. The native vegetation consists predominantly of oak and oak-pine woodlands. Predominant oak species include scarlet (Quercus coccineacata Michx.), black (Quercus velutina Lam.), and white (Quercus alba L.) oaks. In the 1960s, areas of the forest were replaced with faster growing loblolly pine to improve economic yields. The forest has experienced several southern pine beetle infestations in recent years, resulting in significant areas of standing dead trees that present hazards to the public as well as increased risk of wildfires (Nobles et al., 2009).

The experimental design was a two-factor, randomized complete block design with nine treatments, each replicated four times, resulting in a total of 36 sample units in four blocks. The treatments consisted of a control (reference), three burning patterns (no-burn, 3- and 9-yr burn cycles), and three levels of thinning (no-thin; light-thin, thin to $75 \mathrm{ft}^{2} /$ acre basal area; and heavy thin, thin to 50 $\mathrm{ft}^{2}$ /acre basal area; Table 1). At the time of soil sampling, the 3-yr burn cycle had been carried out three times and the 9-yr burn cycle sites had been burnt once (6-yr since the first burn). The reference site was converted to loblolly pines in the 1960s but has not received any burn or thinning treatment since its conversion. Thinning was implemented by removing competing loblolly pine species to release such native hardwood species as oak. 


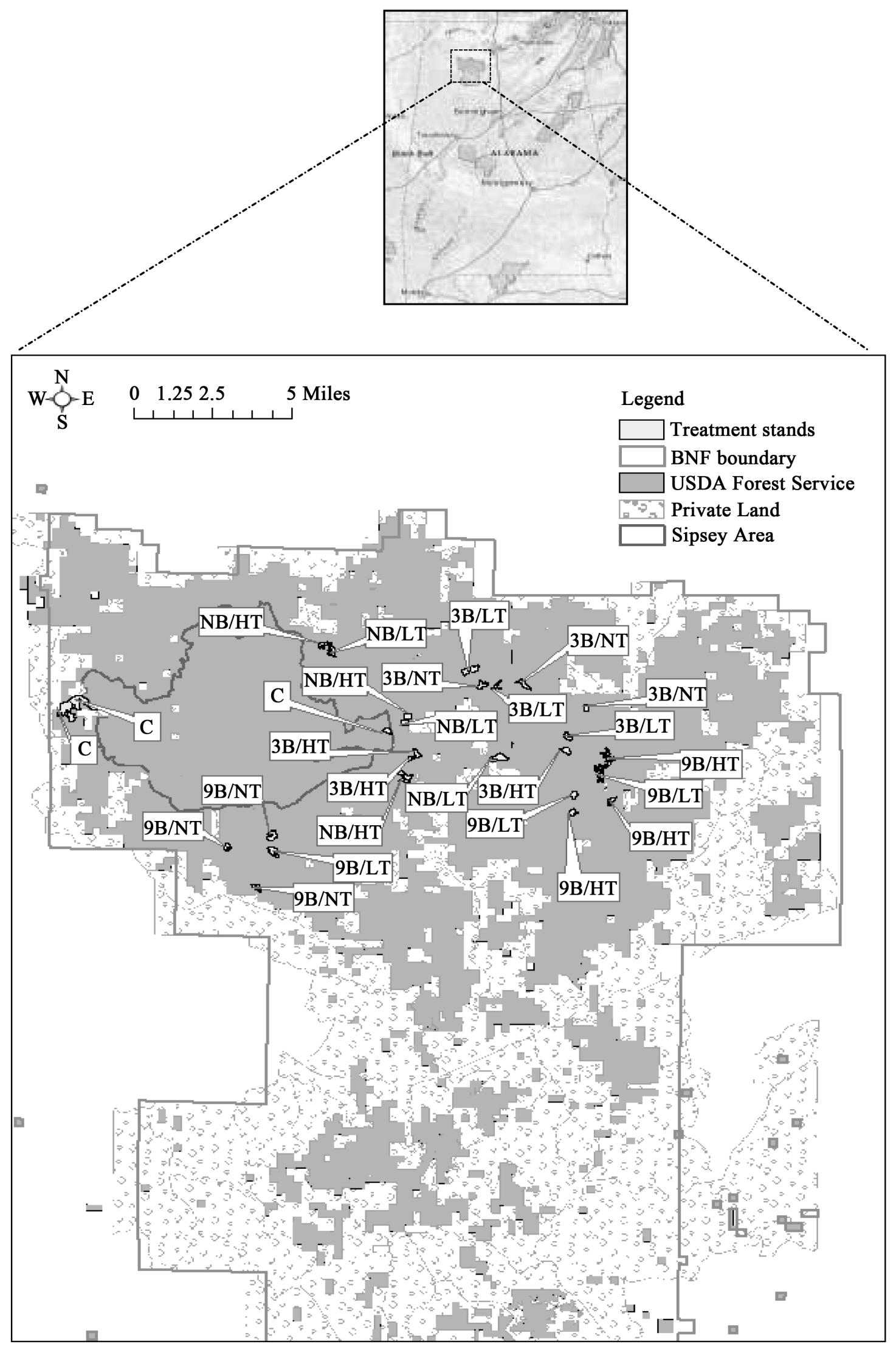

Figure 1. Map of the Bankhead national forest showing treatment sites. 
Table 1. Soil biological, chemical and physical properties.

\begin{tabular}{|c|c|c|c|c|c|c|c|c|c|}
\hline & Treatment & Burning & $\mathrm{pH}$ & $\begin{array}{c}\mathrm{C} \\
(\%)\end{array}$ & $\begin{array}{l}\mathrm{N} \\
(\%)\end{array}$ & $\begin{array}{c}S \\
(\%)\end{array}$ & $\begin{array}{l}\mathrm{C} / \mathrm{N} \\
\text { ratio }\end{array}$ & $\begin{array}{c}\mathrm{MBC} \\
\text { (mg/g } \\
\text { soil) }\end{array}$ & $\begin{array}{c}\text { MBN } \\
\text { (mg/g } \\
\text { soil) }\end{array}$ \\
\hline Control & C & none & $\begin{array}{c}4.51 \\
(0.29)\end{array}$ & $\begin{array}{c}3.11 \\
(0.59)\end{array}$ & $\begin{array}{c}0.13 \\
(0.02)\end{array}$ & $\begin{array}{c}0.02 \\
(0.00)\end{array}$ & $\begin{array}{l}24.42 \\
(1.06)\end{array}$ & $\begin{array}{l}448.05 \\
(56.5)\end{array}$ & $\begin{array}{l}68.03 \\
(9.41)\end{array}$ \\
\hline $\begin{array}{l}\text { No-Burn/ } \\
\text { Light-Thin }\end{array}$ & $\mathrm{NB} / \mathrm{LT}$ & none & $\begin{array}{c}4.37 \\
(0.12)\end{array}$ & $\begin{array}{c}3.49 \\
(0.80)\end{array}$ & $\begin{array}{c}0.13 \\
(0.02)\end{array}$ & $\begin{array}{c}0.01 \\
(0.00)\end{array}$ & $\begin{array}{l}26.54 \\
(2.98)\end{array}$ & $\begin{array}{l}464.60 \\
(31.3)\end{array}$ & $\begin{array}{l}66.03 \\
(4.61)\end{array}$ \\
\hline $\begin{array}{c}\text { No-Burn/ } \\
\text { Heavy-Thin }{ }^{\dagger}\end{array}$ & $\mathrm{NB} / \mathrm{HT}$ & none & $\begin{array}{c}4.73 \\
(0.05)\end{array}$ & $\begin{array}{c}2.47 \\
(0.26)\end{array}$ & $\begin{array}{c}0.10 \\
(0.01)\end{array}$ & $\begin{array}{c}0.01 \\
(0.00)\end{array}$ & $\begin{array}{l}16.47 \\
(7.88)\end{array}$ & $\begin{array}{l}471.60 \\
(38.5)\end{array}$ & $\begin{array}{l}68.26 \\
(5.28)\end{array}$ \\
\hline $\begin{array}{l}\text { 3yr-Burn/ } \\
\text { No-Thin }\end{array}$ & $3 \mathrm{~B} / \mathrm{NT}$ & $3 \mathrm{yr}$ & $\begin{array}{c}4.39 \\
(0.06)\end{array}$ & $\begin{array}{c}2.37 \\
(0.15)\end{array}$ & $\begin{array}{c}0.10 \\
(0.00)\end{array}$ & $\begin{array}{c}0.01 \\
(0.00)\end{array}$ & $\begin{array}{l}23.48 \\
(0.95)\end{array}$ & $\begin{array}{l}455.94 \\
(22.1)\end{array}$ & $\begin{array}{l}71.84 \\
(2.82)\end{array}$ \\
\hline $\begin{array}{l}\text { 3yr-Burn/ } \\
\text { Light-Thin }^{*}\end{array}$ & $3 \mathrm{~B} / \mathrm{LT}$ & $3 \mathrm{yr}$ & $\begin{array}{c}4.68 \\
(0.11)\end{array}$ & $\begin{array}{c}1.90 \\
(0.09)\end{array}$ & $\begin{array}{c}0.09 \\
(0.01)\end{array}$ & $\begin{array}{c}0.01 \\
(0.00)\end{array}$ & $\begin{array}{l}21.35 \\
(0.99)\end{array}$ & $\begin{array}{c}312.76 \\
(8.1)\end{array}$ & $\begin{array}{l}48.94 \\
(1.47)\end{array}$ \\
\hline $\begin{array}{c}\text { 3yr-Burn/ } \\
\text { Heavy-Thin }{ }^{\dagger}\end{array}$ & $3 \mathrm{~B} / \mathrm{HT}$ & $3 \mathrm{yr}$ & $\begin{array}{c}4.99 \\
(0.07)\end{array}$ & $\begin{array}{c}1.97 \\
(0.14)\end{array}$ & $\begin{array}{c}0.09 \\
(0.00)\end{array}$ & $\begin{array}{c}0.01 \\
(0.00)\end{array}$ & $\begin{array}{l}23.18 \\
(0.45)\end{array}$ & $\begin{array}{c}334.05 \\
(58.8)\end{array}$ & $\begin{array}{l}56.04 \\
(8.91)\end{array}$ \\
\hline $\begin{array}{l}\text { 9yr-Burn/ } \\
\text { No-Thin }\end{array}$ & $9 \mathrm{~B} / \mathrm{NT}$ & $9 \mathrm{yr}$ & $\begin{array}{c}4.36 \\
(0.10)\end{array}$ & $\begin{array}{c}2.99 \\
(0.26)\end{array}$ & $\begin{array}{c}0.12 \\
(0.01)\end{array}$ & $\begin{array}{c}0.01 \\
(0.00)\end{array}$ & $\begin{array}{l}24.72 \\
(1.49)\end{array}$ & $\begin{array}{l}433.46 \\
(35.5)\end{array}$ & $\begin{array}{l}66.66 \\
(6.07)\end{array}$ \\
\hline $\begin{array}{l}\text { 9yr-Burn/ } \\
\text { Light-Thin }\end{array}$ & 9B/LT & $9 \mathrm{yr}$ & $\begin{array}{c}4.75 \\
(0.11)\end{array}$ & $\begin{array}{c}2.38 \\
(0.18)\end{array}$ & $\begin{array}{c}0.11 \\
(0.01)\end{array}$ & $\begin{array}{c}0.02 \\
(0.01)\end{array}$ & $\begin{array}{l}21.37 \\
(1.19)\end{array}$ & $\begin{array}{l}258.01 \\
(43.1)\end{array}$ & $\begin{array}{l}32.63 \\
(9.41)\end{array}$ \\
\hline $\begin{array}{c}\text { 9yr-Burn/ } \\
\text { Heavy-Thin }{ }^{\dagger}\end{array}$ & $9 \mathrm{~B} / \mathrm{HT}$ & $9 \mathrm{yr}$ & $\begin{array}{c}4.70 \\
(0.09)\end{array}$ & $\begin{array}{c}1.59 \\
(0.31)\end{array}$ & $\begin{array}{c}0.08 \\
(0.01)\end{array}$ & $\begin{array}{c}0.01 \\
(0.00)\end{array}$ & $\begin{array}{l}19.30 \\
(1.15)\end{array}$ & $\begin{array}{c}299.28 \\
(95.1)\end{array}$ & $\begin{array}{c}43.72 \\
(19.73)\end{array}$ \\
\hline
\end{tabular}

${ }^{\dagger}$ Heavily thinned sites: Thin to $50 \mathrm{ft}^{2} \cdot \mathrm{acre}^{-1}$ basal area (50\% thinning); lightly thinned sites: Thin to 75 $\mathrm{ft}^{2} \cdot$ acre $^{-1}$ basal area (25\% thinning). Standard error values are in parentheses.

\subsection{Soil Sampling and Analysis}

Soils used for this study were collected in 2009 with an auger $(10 \mathrm{~cm}$ inner diameter) from 0 to $10 \mathrm{~cm}$ depth in three replicates after removing surface residue. Half of the soil samples were air-dried, ground, and passed through a $2-\mathrm{mm}$ sieve and stored in plastic bags, while the other half were stored at $4^{\circ} \mathrm{C}$ until used. The air-dried samples were utilized for physicochemical properties; whereas, the soils kept at $4^{\circ} \mathrm{C}$ was used for microbial biomass carbon (MBC), and enzyme metabolic analysis. Soil $\mathrm{pH}$ was measured in water at a soil to solution ratio of 1:2 and temperature compensated at $25^{\circ} \mathrm{C}$. Total $\mathrm{C}, \mathrm{N}$, and $\mathrm{S}$ in the soils were determined by a dry combustion method using a vario Max CNS analyzer. The soil microbial biomass carbon (MBC) was estimated using the chloroform fumigation-incubation method (Franzluebbers et al., 1995). Microbial biomass nitrogen (MBN) was determined from $10 \mathrm{~g}$ of the fumigated and incubated soil samples, extracted with $50 \mathrm{~mL}-0.5 \mathrm{~mol} / \mathrm{L} \mathrm{K}_{2} \mathrm{SO}_{4}$ for $1 \mathrm{~h}(1: 5 \mathrm{Wt} / \mathrm{V}$ ratio). The obtained organic $\mathrm{N}$ and $\mathrm{NH}_{4}-\mathrm{N}$ was oxidized to $\mathrm{NO}_{3}-\mathrm{N}$ by persulfate (Cabrera \& Beare, 1993) and the $\mathrm{N}$ concentration determined with ammonium-nitrate ana- 
lyzer (Timberline instrument, model no. TL-2800). Microbial biomass nitrogen $(\mathrm{MBN})$ was calculated as the difference between $\mathrm{NO}_{3}-\mathrm{N}$ concentrations in the sample before and after fumigation incubation and divided by a factor of 0.41 (Carter \& Rennie, 1982).

Soil microbial community compositions were characterized using the ester-linked fatty acid methyl ester (EL)-FAME analysis as described by Schutter \& Dick (2000). Lipids extraction from $3 \mathrm{~g}$ of field-moist soil, employed mild alkaline methanolysis ( $15 \mathrm{~mL}$ of $0.2 \mathrm{M} \mathrm{KOH}$ in methanol), followed by neutralization with $3 \mathrm{~mL}$ of $1.0 \mathrm{M}$ acetic acid. FAMEs were then partitioned into organic phase by adding $10 \mathrm{~mL}$ of hexane followed by centrifugation at $480 \times \mathrm{g}$ for 10 $\min$ at $37^{\circ} \mathrm{C}$. The hexane layer was transferred to a clean glass test tube and the hexane evaporated under a $\mathrm{N}_{2}$ stream. FAME was dissolved by adding $200 \mu \mathrm{L}$ of 1:1 methyl tert-butyl ether and hexane containing methyl nonadecanoate (19:0) as an internal standard $(0.5 \mathrm{mg} \cdot \mathrm{ml}-1)$. Samples were vortexed and transferred into a $250-\mu \mathrm{L}$ glass insert in a $2-\mathrm{mL}$ GC vial. FAME analysis was conducted in an Agilent $6890 \mathrm{~N}$ gas chromatograph with a $25 \mathrm{~m} \times 0.32 \mathrm{~mm} \times 0.25 \mu \mathrm{m}(5 \%$ phenyl)-methylpolysiloxane Agilent HP-5 fused silica capillary column (Agilent, Santa Clara, CA) and flame ionization detector (Hewlett Packard, Palo Alto, CA) with ultra-high purity hydrogen as the carrier gas. The temperature program ramped from $170^{\circ} \mathrm{C}$ to $270^{\circ} \mathrm{C}$ at $5^{\circ} \mathrm{C} \mathrm{min}^{-1}$ then ramped to $300^{\circ} \mathrm{C}$ for $2 \mathrm{~min}$ (Acosta-Martínez et al., 2010; Gardner et al., 2011).

Fatty acids were identified and quantified based on comparison of retention times and peak areas to components of MIDI standards using the TSBA6 aerobe program from MIDI (Microbial ID, Inc., Newark, DE). FAMEs are described by the number of $\mathrm{C}$ atoms, a colon, the number of double bonds, and the position of the first double bond from the methyl $(\omega)$ end of the molecule. Other notations used include methyl $(\mathrm{Me})$, cis $(c)$ and trans $(t)$ isomers, and iso $(i)$ and anteiso (a) branched FAMEs. Selected FAMEs used as microbial markers were Gram-positive (Gram+) bacteria (i15:0, a15:0, i17:0, a17:0), Gram-negative (Gram-) bacteria (cy17:0, cyl9:0), and actinomycetes (10Me17:0, 10Me18:0). Fungal markers that included saprophytic fungi $(18: 1 \omega 9 c, 18: 3 \omega 6 c)$, arbuscular mycorrhizal fungi (AMF) (16:1 $\omega 5 \mathrm{c})$ and absolute amounts of FAMEs (nmolg-1 soil) were calculated as described by Zelles (1999). Bacterial summation was calculated using the Gram+, Gram-, and actinomycetes markers; while fungal summation was calculated using both saprophytic and AMF fungal markers, and the fungal/bacteria (F:B) ratio calculated by dividing the sum of fungi by the sum bacteria.

\subsubsection{Enzyme Metabolic Analysis}

The activities of three hydrolases, $\beta$-glucosidase $(\beta$-Gluc), $\beta$-glucosaminidase $(\beta-\mathrm{Glm})$ and arylsulfatase (Aryl) were determined in this forest soil. Briefly, $1 \mathrm{~g}$ of air-dried soil was assayed under a final concentration of $10 \mathrm{~m} M$ of the specific enzyme substrate ( $p$-nitrophenyl-derivate), optimal $\mathrm{pH}$ and buffer (without toluene), and incubated for $1 \mathrm{~h}$ at $37^{\circ} \mathrm{C}$ as described in Tabatabai (1994) and 
Parham and Deng (2000). The concentration of the reaction product ( $p$-nitrophenol) was determined colorimetrically at $400 \mathrm{~nm}$ using a spectrophotometer (Beckman Coulter DU640, Brea, CA). Samples were assayed in duplicate and included a control for each assay, where the substrate was added after the reaction was stopped following incubation. The amount of $p$-nitrophenol released was calculated by reference to a calibration curve developed with standards containing $0,100,200,300,400$, and $500 \mathrm{nmol}$ of p-nitrophenol.

Xylanase activities were determined according to the procedure described by Deng \& Tabatabai, (1994). The protocol used involved the release of reducing sugars after hydrolysis of artificial substrates (xylan). In short, a gram $(1 \mathrm{~g})$ of soil was weighed and mixed with $0.2 \mathrm{~mL}$ toluene in a 50-mL Erlenmeyer flask. The flask was placed under a fume hood for 15 min after which $20 \mathrm{~mL}$ of the respective substrate solution was added. A rubber stopper was used to cap the flask, and the solution mixed thoroughly before incubating for $24 \mathrm{~h}$ at $30^{\circ} \mathrm{C}$. After incubation, it was transferred into a centrifuge tube and centrifuged at 17,000 $\mathrm{rpm}$ for $10 \mathrm{~min}$ at $4^{\circ} \mathrm{C}$. The supernatant was filtered through a Whatman paper No. 42 and reducing sugars quantified using the Somogyi-Nelson colorimetric method (Deng \& Tabatabai, 1994). Acid phosphatase activities were assayed according to Tabatabai (1994) and described in Bottomley et al. (1994). Briefly, one gram of soil, substrate $(1 \mathrm{~mL}, 50 \mathrm{mmol} / \mathrm{L} p$-nitrophenyl phosphate), and toluene $(0.2 \mathrm{~mL})$ were incubated in $4 \mathrm{~mL}$ of $\mathrm{MUB}(\mathrm{pH} 6.5)$ at $37^{\circ} \mathrm{C}$ for $1 \mathrm{~h}$. At the end of incubation, the activity was stopped by adding $1 \mathrm{~mL}$ of $0.5 \mathrm{~mol} / \mathrm{L} \mathrm{CaCl}_{2}$ and $4 \mathrm{~mL}$ of $0.5 \mathrm{~mol} / \mathrm{L} \mathrm{NaOH}$, shaken, filtered and the absorbance read at 420 $\mathrm{nm}$ using a UV/Vis spectrophotometer.

Laccase and manganese-dependent peroxidase activities were measured as described by De Souza-Cruz et al. (2004). Laccase was assayed using ABTS (2, 2-azino-bis (3-ethylbenzthiazoline-6-sulfonic acid). Reactions was carried out in $3 \mathrm{~mL}$ curvets containing $0.6 \mathrm{~mL}$ of $200 \mathrm{mM}$ sodium phosphate/100 mM citric acid buffer at $\mathrm{pH} 5.0,0.2 \mathrm{~mL}$ of water, $1.0 \mathrm{~mL}$ of soil homogenate and $0.2 \mathrm{~mL}$ of $1.0 \mathrm{mM}$ substrate and absorbance measured at $420 \mathrm{~nm}$. For manganese peroxidase assay, the reaction mixtures contained $1.0 \mathrm{~mL}$ sodium succinate buffer ( 50 $\mathrm{mM}, \mathrm{pH} 4.5), 1.0 \mathrm{~mL}$ sodium lactate (50 mM, pH 5.0), $0.4 \mathrm{~mL}$ manganese sulfate $(0.1 \mathrm{mM}), 0.7 \mathrm{~mL}$ phenol red $(0.1 \mathrm{mM}), 0.4 \mathrm{~mL} \mathrm{H} \mathrm{O}_{2}(50 \mu \mathrm{M})$, gelatin $(1 \mathrm{mg}$ $\mathrm{mL}-1)$, and soil homogenate $(0.5 \mathrm{~mL})$. One $\mathrm{mL}$ of the reaction mixture was added to $40 \mu \mathrm{L}$ of $5 \mathrm{NNaOH}$ solution and absorbance measured at $610 \mathrm{~nm}$.

\subsubsection{Statistical Analysis}

Analysis of variance (ANOVA) followed by a Turkey test was performed using SAS statistical package software version 9.3 (SAS Institute, Cary, North Carolina, USA). Analysis was performed to detect differences in various enzyme activities. Results were considered significant at $P<0.05$. A correlation analysis (Pearson) was also performed using SPSS software to determine whether there was significant correlation between enzyme activities, soil properties, and microbial indices. Data was log transformed if not normally distributed before analysis. 


\section{Results}

\subsection{Soil Organic Matter Dynamics and Microbial Biomass Carbon and Nitrogen}

Like most forest soils, the $\mathrm{pH}$ values are low, ranged from $4.36 \pm 0.10$ to $4.99 \pm$ 0.07 , while $\mathrm{C}: \mathrm{N}$ ranged from $16.47 \pm 7.88$ to $26.54 \pm 2.98$, suggesting possible high mineralization rates in the soils (Table 1 ). Total $\mathrm{C}, \mathrm{N}$, and $\mathrm{S}$ contents were as high as $3.49 \% \pm 0.80 \%, 0.13 \% \pm 0.02 \%, 0.02 \% \pm 0.00 \%$, respectively. The NB/LT (no-burn, lightly-thinned) plots had the highest total C, and N, as well as $\mathrm{C} / \mathrm{N}$ ratio. In the heavily-thinned and frequently burned (3-yr burn) plots there was a decrease in total $\mathrm{C}$ and $\mathrm{N}$ contents; however, there was no significant difference in the $\mathrm{C}: \mathrm{N}$ ratios and total S. Microbial biomass $\mathrm{C}$ ranged from $258.01 \pm$ 43.10 to $471.60 \pm 38.50$ while $\mathrm{MBN}$ ranged from $32.63 \pm 9.41$ to $71.84 \pm 2.82$. The high standard deviations indicate a high level of variability in the soils. Both the 9-yr burned plot and the lightly-thinned plots showed a decrease in $\mathrm{MBN}$, while the 9-yr burned plot resulted in an additional decrease in MBC (Table 1).

\subsection{Enzyme Metabolisms and Microbial Community Compositions}

Among the enzymes evaluated, only $\beta$-glucosidase and arylsulfatase showed interactions within thinned and burned plots. The ligninolytic enzymes (laccase and $\mathrm{MnP}$ ) responded differently in the burned and thinned plots compared to the hydrolytic ( $\beta$-glucosidase, $\beta$-glucosaminidase, and acid phosphatase) enzymes. There was increased MnP activity in thinned plots of the burned cycle (Figure 2). In contrast, $\beta$-glucosidase activity was significantly higher in the control than in most plots. $\beta$-glucosaminidase activity varied significantly in burned plots, but in general, it showed similar trends for $\beta$-glucosidase activity. Arylsulfatase activity was significantly higher in the 9-yr-burned/heavily-thinned plots than in most plots.

We observed significant but negative correlations between the ligninolytic laccase and manganese peroxidase ( $\mathrm{Lac}$ and $\mathrm{MnP}$ ) enzymes respectively, with $\operatorname{MBC}\left(-0.45^{*}\right.$ and $-0.68^{* *}$ respectively) and $\mathrm{MBN}\left(-0.43^{\star}\right.$ and $-0.65^{\star *}$ respectively). Total $\mathrm{C}, \mathrm{N}$, and $\mathrm{S}$ showed significant and positive correlations with $\beta$-glucosidase $\left(0.66^{\star *}, 0.68^{\star *}, 0.51^{\star}\right.$ respectively) and acid phosphatase $\left(0.64^{\star *}\right.$, $0.64^{\star *}, 0.60^{* *}$ respectively) activities. Total $\mathrm{C}$ and $\mathrm{N}$ had significant but negative correlations with manganese peroxidase $\left(-0.50^{\star},-0.43^{\star}\right.$ respectively). Soil pH was significantly and positively correlated with laccase $\left(0.46^{*}\right)$ and manganese peroxidase $\left(0.52^{\star}\right)$ activities but negatively correlated with $\beta$-glucosidase $\left(-0.46^{*}\right)$ activity (Table 2$)$.

Microbial community size, determined based on a total of 12 FAMEs, was greater in the lightly-thinned plots regardless of the burned cycle (no-burned, 3-yr-burned and 9-yr-burned) and in 3-yr-burned/heavily-thinned plots compared to the control (Table 3). Like total FAMEs, the sum of fungal FAMEs showed significant differences with the lightly-thinned plots at all burned levels, 
Table 2. Correlation analysis between enzyme activities and soil properties.

\begin{tabular}{ccccccc}
\hline & $\mathrm{pH}$ & $\mathrm{C}$ & $\mathrm{N}$ & $\mathrm{S}$ & $\mathrm{MBC}$ & $\mathrm{MBN}$ \\
\hline Laccase & $0.46^{*}$ & -0.33 & -0.13 & 0.07 & $-0.45^{*}$ & $-0.43^{*}$ \\
Manganese peroxidase & $0.52^{*}$ & $-0.50^{*}$ & $-0.43^{*}$ & -0.09 & $-0.68^{* *}$ & $-0.65^{* *}$ \\
Xylase & -0.33 & 0.24 & 0.22 & 0.18 & 0.07 & 0.05 \\
$\beta$-Glucosidase & $-0.46^{*}$ & $0.66^{* *}$ & $0.68^{* *}$ & $0.51^{*}$ & 0.20 & 0.15 \\
$\beta$-Glucosamidase & -0.32 & 0.22 & 0.32 & 0.21 & 0.26 & 0.14 \\
Acid phosphatase & -0.33 & $0.64^{* *}$ & $0.64^{* *}$ & $0.60^{* *}$ & -0.11 & -0.19 \\
Arylsulfatase & 0.18 & 0.02 & 0.22 & 0.30 & -0.34 & -0.35 \\
\hline
\end{tabular}

The R-values for Pearson's correlation coefficients, significant at $P<0.05$ designated by one asterisk $\left({ }^{*}\right)$ and significant at $P<0.01$ designated by two asterisks $\left.{ }^{* *}\right)$; microbial biomass carbon (MBC); microbial biomass nitrogen $(\mathrm{MBN})$.

Table 3. Percent change in FAME indicators for different microbial groups relative to the control site.

\begin{tabular}{|c|c|c|c|c|c|c|c|c|c|}
\hline \multirow{3}{*}{ Parameter } & \multirow{2}{*}{$\begin{array}{l}\text { Control } \\
\text { No burn } \\
\text { or thin }\end{array}$} & \multicolumn{2}{|c|}{ No burn } & \multicolumn{3}{|c|}{ 3yr burn } & \multicolumn{3}{|c|}{$9 y r$ burn } \\
\hline & & $\begin{array}{l}\text { light } \\
\text { thin }\end{array}$ & $\begin{array}{c}\text { heavy } \\
\text { thin }\end{array}$ & $\begin{array}{l}\text { No } \\
\text { thin }\end{array}$ & $\begin{array}{l}\text { light } \\
\text { thin }\end{array}$ & $\begin{array}{c}\text { heavy } \\
\text { thin }\end{array}$ & No thin & $\begin{array}{l}\text { light } \\
\text { thin }\end{array}$ & $\begin{array}{c}\text { heavy } \\
\text { thin }\end{array}$ \\
\hline & nmols $\cdot \mathrm{g}^{-1}$ & \multicolumn{8}{|c|}{$\%$ difference } \\
\hline Bacteria (B) & 195.1 & 25.1 & -60.5 & -30.2 & 34.6 & 12.2 & -65.0 & 37.3 & -10.7 \\
\hline Gramt & 68.44 & 37.7 & -55.2 & -100 & 66.5 & 22.7 & -85.6 & 24.7 & -15.1 \\
\hline i15:0 & 34.6 & 44.7 & -58.2 & -100 & 49.5 & 5.3 & -100 & 14.5 & -22.4 \\
\hline$a 15: 0$ & 14.0 & 32.3 & -44.1 & -100 & 70.3 & 57.9 & -100 & 48.2 & -12.2 \\
\hline$i 17: 0$ & 10.2 & 38.8 & -55.0 & -100 & 120.9 & 39.3 & -47.2 & 37.6 & 15.8 \\
\hline$a 17: 0$ & 9.8 & 19.5 & -60.3 & -100 & 64.2 & 16.6 & -53.8 & 13.8 & -25.6 \\
\hline Gram- & 106.8 & 16.0 & -64.9 & 27.4 & 12.2 & 0.6 & -45.4 & 46.1 & -4.2 \\
\hline cy17:0 & 14.6 & -20.5 & -73.0 & 17.7 & 2.3 & -16.7 & -61.3 & 25.1 & -25.2 \\
\hline cy19:0 & 92.2 & 21.8 & -63.6 & 28.9 & 13.8 & 3.4 & -42.9 & 49.5 & -0.9 \\
\hline Actinomycetes & 19.8 & 31.3 & -55.8 & -100 & 44.9 & 38.3 & -100 & 32.9 & -30.6 \\
\hline 10-Me 17:0 & 6.4 & 17.8 & -63.9 & -100 & 31.4 & -5.6 & -100 & 9.2 & -40.2 \\
\hline 10-Me 18:0 & 13.4 & 37.6 & -51.9 & -100 & 51.3 & 59.1 & -100 & 44.1 & -26.1 \\
\hline Fungi (F) & 182.5 & 18.8 & -55.2 & -100 & 27.6 & 27.1 & -100 & -11.3 & -42.7 \\
\hline $16: 1 \omega 5 c$ & 20.0 & 19.0 & -54.3 & -100 & 74.2 & 30.4 & -100 & 36.9 & -17.5 \\
\hline $18: 3 \omega 6 c$ & 30.0 & -64.1 & -43.0 & -100 & -100 & 14.8 & -100 & -100 & -100 \\
\hline $18: 1 \omega 9 c$ & 132.6 & 37.5 & -58.0 & -100 & 49.5 & 29.4 & -100 & 1.5 & -33.5 \\
\hline \multicolumn{10}{|l|}{ Protozoa } \\
\hline $20: 4 \omega 6 c$ & 6.2 & 3.4 & -72.1 & -14.5 & 2.7 & -17.9 & -35.9 & 33.1 & -13.4 \\
\hline F/B ratio & 0.9 & -5.3 & 12.8 & -100 & -5.3 & 12.8 & -100 & -36.2 & -36.2 \\
\hline Total FAME & 383.8 & 21.8 & -58.2 & -63.2 & 30.8 & 18.8 & -81.2 & 14.1 & -26.0 \\
\hline
\end{tabular}

Values in bold represent percent increase, while the negative values represent percent decrease in abundance relative to the reference site. 


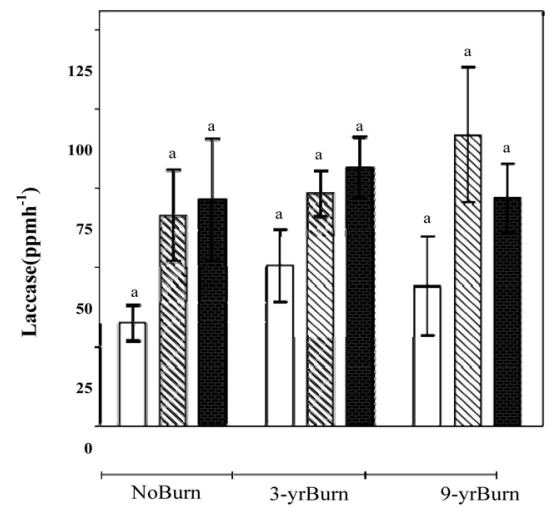

(a)

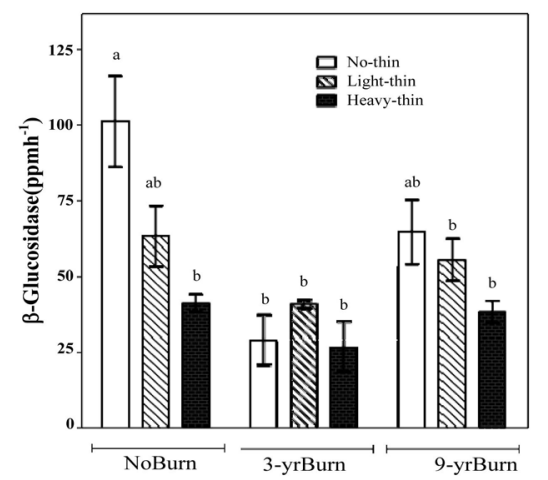

(c)

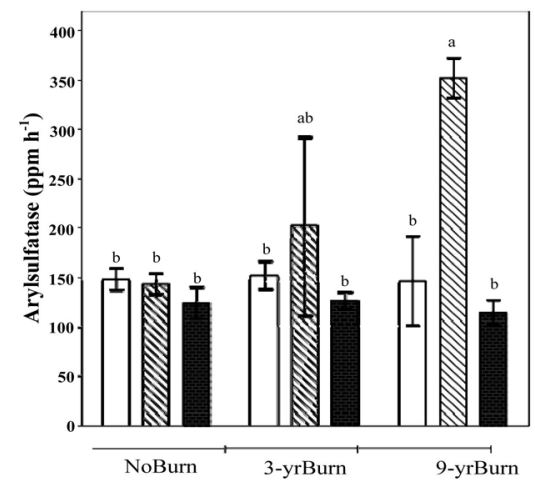

(e)

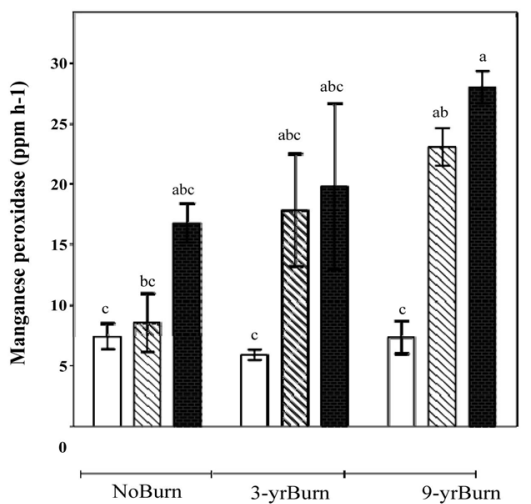

(b)

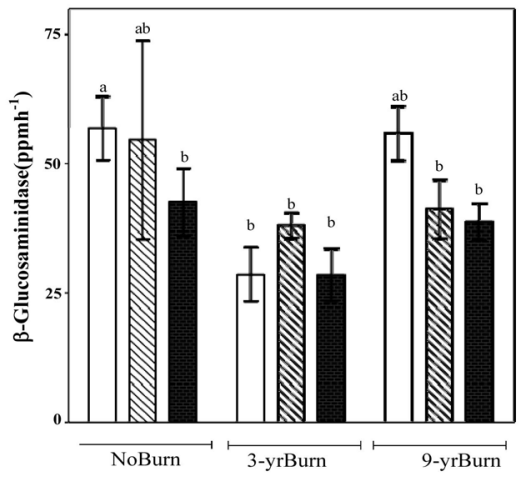

(d)

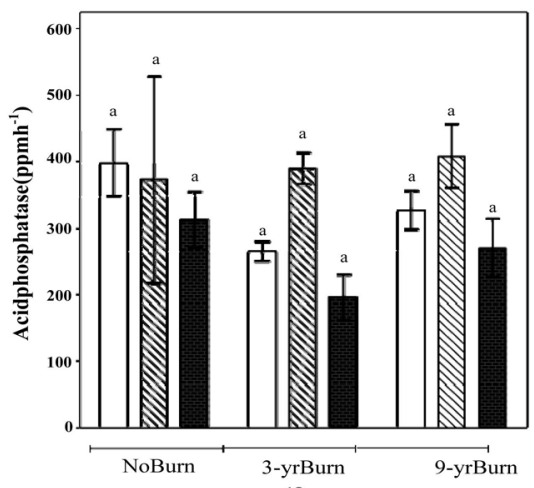

(f)

Figure 2. Enzymatic activities involved in lignin degradation ((a) and (b)), C and N cycling ((c) and (d)), S and P cycling ((e) and (f)). Same letters imply means are not significantly different at $P<0.05$, while different lettered bars are significantly different at $P<$ 0.05 .

and at the 3-yr-burned and heavily-thinned plots. Total bacterial FAMEs showed similar patterns as the fungal indicators, except that the fungal FAMEs decreased in the 9-B/LT plots. Although not significantly different, the multivariate analysis also revealed an increase in bacterial FAMEs and a decrease in fungal FAMEs, with increasing burning frequency. Although a similar pattern was noted for protozoa, the percentage $(2.7 \%-3.4 \%)$ difference in the lightly-thinned plots with respect to the control was lower than the other microbial groups in the no-burned and 3-yr-burned plots. The fungi: bacteria (F: B) ratio was generally 
higher for heavily-thinned plots than the lightly-thinned plots. Gram-positive bacteria (i15:0, a15:0, i17:0, and a17:0), actinomycetes (10-Me17:0, 10-Me18:0),

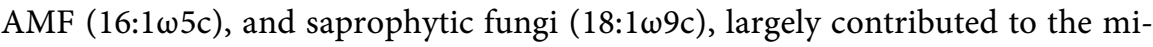
crobial compositions.

\section{Discussion}

\section{Impact of Prescribed Burning and Tree Thinning Management Selections}

Our study demonstrated that the C: $\mathrm{N}$ ratios and total $\mathrm{C}$ seemed not to be affected by thinning practices. In fact, heavily-thinned plots without burning or less frequent burning ( $\mathrm{NB} / \mathrm{HT}$ and $9-\mathrm{B} / \mathrm{HT})$ treatments seemed to provide more favorable conditions (higher $\mathrm{pH}$ and lower $\mathrm{C}: \mathrm{N}$ ratios) for $\mathrm{C}$ and $\mathrm{N}$ mineralization. High temperatures generated during fire treatments will change the chemical structures of substrates and SOM, likely to impact post-fire soil $\mathrm{pH}$, moisture, and nutrient contents. Although the soil $\mathrm{pH}$ did not vary significantly between the nine plots, the burned plots treatments seemed to have slightly higher soil $\mathrm{pH}$ with increased burning frequency. Certini (2005) indicated significant increases in $\mathrm{pH}$ at high temperatures $\left(>450^{\circ} \mathrm{C}-500^{\circ} \mathrm{C}\right)$, especially with the complete combustion of fuel and the consequent release of cation bases. Cations may remain onsite after burning in the form of ash or uncombusted hydrocarbons. However, if the ash formed is subsequently leached into the soil, they exchange with $\mathrm{H}+$ ions, which increase the $\mathrm{pH}$.

Evaluation of all the plots using FAME profiling, as another indicator of microbial community size, revealed an increase in total FAMEs in the lightly-thinned plots and a decrease in the heavily-thinned plots (except in the 3-yr burned/heavily-thinned plots) compared to the control. The decrease in the microbial populations (total FAME) in the heavy thinned-only plots (as with $\mathrm{NB} / \mathrm{HT}$ ) and heavy thinned plots with less frequent burning $(9-\mathrm{B} / \mathrm{HT})$, may in part be due to a reduction in fine root biomass in the heavily thinned plots, likely to reduce $\mathrm{C}$ availability for microbial growth. Although microbial growth and activities are usually limited by C availability, Kelliher et al. (2004) showed microbial activities in soils to be significantly limited by low moisture contents than due to $\mathrm{C}$ or $\mathrm{N}$ in the ponderosa pine forest in Oregon (Grayston \& Rennenberg, 2006).

The slight increase (by 12\%) in fungi:bacteria (F:B) ratio in heavily-thinned plots relative to the control could be attributed to the relatively high deposition of recalcitrant plant materials in the heavily-thinned plots. The surface addition of woody residues in conifer forests has been shown to increase F:B ratios (Brant et al., 2006; Busse et al., 2009). Studies of other forest ecosystems have shown that $\mathrm{F}: \mathrm{B}$ ratios varied in response to forest fertility, and the relative abundance of bacteria increasing in response to increased fertility (Boyle et al., 2008). However, response of $\mathrm{F}: \mathrm{B}$ ratios was not detected for the heavily thinned plots with 9-yr-burning, which may be due to a relatively high FAME (i17:0), indicative of 
Gram-positive bacteria and reduction in fungi FAME (18:3 $\omega 6 \mathrm{c})$ indicator, not detected in this plot. The protozoa $(20: 4 \omega 6 c)$ was higher in the lightly-thinned plots at all burned cycles and was significantly and positively correlated with the bacterial groups. Protozoa abundance can change microbial compositions within ecosystems because they feed selectively on different bacteria species (Bonkowski et al., 2000; Batten et al., 2006). This can lead to shifts in bacterial communities favoring those with a higher percentage of plant growth-promoting rhizobacteria (Batten et al., 2006).

Our study showed a decrease in microbial biomass $\mathrm{C}$ and $\mathrm{N}$ in the 9-yr burned plot/lightly thinned plot, reflecting significant modifications in SOM chemistry due to the depletion of labile $\mathrm{C}$ sources with the high temperatures leaving only recalcitrant $\mathrm{C}$ sources as available $\mathrm{C}$ substrates to soil microbial communities. The changes observed in a forest ecosystem with burning resemble the impacts of adding biochar to soils and the changes in SOM dynamics that it causes. Similar to this study, Kelly et al. (2015) reported that additions of switchgrass biochar at different levels to two different soils caused an increase in soil $\mathrm{pH}$, decreased $\mathrm{N}$ mineralization and changed microbial community compositions towards a decrease in fungal populations. Increase in bacterial FAMEs and decrease in fungal FAMEs may be attributed to higher soil $\mathrm{pH}$ associated with frequent burning, and increase adaptations with pyromorphic compounds (e.g., fire-induced charcoal). Pietikåinen \& Fritze (1995) reported that burning favors bacterial populations over fungal populations especially in coniferous forest ecosystems. In this forest, the shift towards bacterial populations was more influenced by an increase in actinomycetes (10Me18:0) than towards other bacterial groups, which are generally involved in decomposition of recalcitrant substrates.

Forest thinning reportedly impacts litter accumulation, soil organic matter, nutrient compositions and microbial substrate utilization (Cookson et al., 2008), which could indicate that several enzyme activities can be affected by this practice. Thinning has also been found to specifically increase laccase activity (Giai \& Boerner, 2007) as we found in this forest ecosystem. Thinned (lightly and heavily) plots showed greater ligninolytic (laccase and $\mathrm{MnP}$ ) activities compared to the no-thinned plots. These enzymes could be used to indicate the significant abundance and roles of basidiomycetes fungi in this forest as they are known producers of MnP (Hofrichter, 2002; Valášková et al., 2007; Šnajdr et al., 2008). Lucas et al. (2007), in a study on soil microbial communities and extracellular enzyme activities in a New Jersey Pinelands, found changes to the soil microbial community compositions that did not indicate any effect on extracellular enzyme metabolic activities. Laccase and manganese peroxidase are involved in the degradation of lignin and other recalcitrant compounds, and their increase is consistent with the rise in low SOM content, attributable to large amounts of woody debris deposited during thinning. Burning increased the rapid decomposition and utilization of the relatively poor organic material because of direct combustion of the more labile organic matter fractions. 
The hydrolases were more affected by thinning practices, for example, the significantly lower $\beta$-glucosidase activities in the heavily-thinned plots can be linked to an increase in the deposition of woody materials with restricted access to cellulose, while the substantially lower enzyme metabolic activities in the 3 -yr-burned cycle plots is likely due to the shorter recovery time for the microbes after prescribed burning. $\beta$-glucosaminidase activity followed a similar trend as $\beta$-glucosidase; however, there was no significant differences due to thinning. Acid phosphatase and arylsulfatase (important for $\mathrm{P}$ and $\mathrm{S}$ cycling respectively) showed lower activities with heavily-thinned plots compared to the control. The difference is possibly due to the lower plant available $\mathrm{P}$ and $\mathrm{S}$ in these plots, while laccase and $\mathrm{MnP}$ metabolic activities are associated with heavy thinning.

\section{Conclusion}

Continuous research on forest ecosystems is needed to bridge gaps in our understanding of microbial compositions and metabolic catalytic processes; given their significance in forest health and quality. Successful forest restoration and regeneration are significantly associated with the efficacy of microbes involved in $\mathrm{C}, \mathrm{N}, \mathrm{S}$, and $\mathrm{P}$ cycling. Changes in the microbial community compositions and metabolisms should be considered in forest management practices.

\section{Acknowledgements}

This project was supported by NSF CREST-CFEA grant, award number 1036600 .

Mention of trade names or commercial products in this publication is solely for providing specific information and does not imply recommendation or endorsement by either Alabama A \& M University (AAMU) and National Science Foundation (NSF).

\section{References}

Acosta-Martínez, V., Dowd, S. E., Bell, C. W., Lascano, R., Booker, J. D., Zobeck, T. M., \& Upchurch, D. R. (2010). Microbial Community Composition as Affected by Dryland Cropping Systems and Tillage in a Semiarid Sandy Soil. Diversity, 2, 910-931. https://doi.org/10.3390/d2060910

Agee, J. K., \& Skinner, C. N. (2005). Basic Principles of Forest Fuel Reduction Treatments. Forest Ecology and Management, 211, 83-96. https://doi.org/10.1016/j.foreco.2005.01.034

Akburak, S., \& Makineci, E. (2015). Thinning Effects on Soil and Microbial Respiration in a Coppice Originated Carpinus betulus L. Stand in Turkey. iForest, 9, 783-790. https://doi.org/10.3832/ifor1810-009

Andersson, M., Michelsen, A., Jensen, M., \& Kjøller, A. (2004). Tropical Savannah Woodland: Effects of Experimental Fire on Soil Microorganisms and Soil Emission of Carbon Dioxide. Soil Biology and Biochemistry, 36, 849-858. https://doi.org/10.1016/j.soilbio.2004.01.015

Baar, J., Horton, T. R., Kretzer, A. M., \& Bruns, T. D. (1999). Mycorrhizal Colonization of Pinus muricata from Resistant Propagules after a Stand-Replacing Wildfire. New Phytologist, 143, 409-418. https://doi.org/10.1046/j.1469-8137.1999.00452.x 
Bååth, E., Frostegård, A. S. A., Pennanen, T., \& Fritze, H. (1995). Microbial Community Structure and pH Response in Relation to Soil Organic Matter Quality in Wood-Ash Fertilized, Clear-Cut or Burned Coniferous Forest Soils. Soil Biology and Biochemistry, 27, 229-240. https://doi.org/10.1016/0038-0717(94)00140-V

Bandick, A. K., \& Dick, R. P. (1999). Field Management Effects on Soil Enzyme Activities. Soil Biology and Biochemistry, 31, 1471-1479. https://doi.org/10.1016/S0038-0717(99)00051-6

Batten, K. M., Scow, K. M., Davies, K. F., \& Harrison, S. P. (2006). Two Invasive Plants Alter Soil Microbial Community Composition in Serpentine Grasslands. Biology Invasions, 8, 217-230. https://doi.org/10.1007/s10530-004-3856-8

Boerner, R. E. J., Decker, K. L. M., \& Kennedy, E. (2000). Prescribed Burning Effects on Soil Enzyme Activity in a Southern Ohio Hardwood Forest: A Landscape-Scale Analysis. Soil Biology and Biochemistry, 32, 899-908.

https://doi.org/10.1016/S0038-0717(99)00208-4

Bonkowski, M., Cheng, W., Griffiths, B. S., Alphei, J., \& Scheu, S. (2000). Microbial-Faunal Interactions in the Rhizosphere and Effects on Plant Growth. European Journal of Soil Biology, 36, 135-147. https://doi.org/10.1016/S1164-5563(00)01059-1

Bottomley, P. S., Angle, J. S., \& Weaver, R. W. (1994). Methods of Soil Analysis: Part 2-Microbiological and Biochemical Properties. Madison, WI: Soil Science Society of America,

Boyle, S. A., Yarwood, R. R., Bottomley, P. J., \& Myrold, D. D. (2008). Bacterial and Fungal Contributions to Soil Nitrogen Cycling under Douglas fir and Red Alder at Two Sites in Oregon. Soil Biology and Biochemistry, 40, 443-451.

https://doi.org/10.1016/j.soilbio.2007.09.007

Brant, J. B., Sulzman, E. W., \& Myrold, D. D. (2006). Microbial Community Utilization of Added Carbon Substrates in Response to Long-term Carbon Input Manipulation. Soil Biology and Biochemistry, 38, 2219-2232. https://doi.org/10.1016/j.soilbio.2006.01.022

Busse, M. D., Sanchez, F. G., Ratcliff, A. W., Butnor, J. R., Carter, E. A., \& Powers, R. F. (2009). Soil Carbon Sequestration and Changes in Fungal and Bacterial Biomass Following Incorporation of Forest Residues. Soil Biology and Biochemistry, 41, 220-227. https://doi.org/10.1016/j.soilbio.2008.10.012

Cabrera, M. L., \& Beare, M. H. (1993). Alkaline Persulfate Oxidation for Determining Total Nitrogen in Microbial Biomass Extract. Soil Science Society of America Journal, 57, 1007-1012. https://doi.org/10.2136/sssaj1993.03615995005700040021x

Carter, M. R., \& Rennie, D. A. (1982). Changes in Soil Quality under Zero Tillage Farming Systems: Distribution of Microbial Biomass and Mineralizable C and N Potentials. Canadian Journal of Soil Science, 62, 587-597. https://doi.org/10.4141/cjss82-066

Certini, G. (2005). Effects of Fire on Properties of Forest Soils: A Review. Oecologia, 143, 1-10. https://doi.org/10.1007/s00442-004-1788-8

Converse, S. J., Block, W. M., \& White, G. C. (2006). Small Mammal Population and Habitat Responses to Forest Thinning and Prescribed Fire. Forest Ecology and Management, 228, 263-273. https://doi.org/10.1016/j.foreco.2006.03.006

Cookson, W. R., O’Donnell, A. J., Grant, C. D., Grierson, P. F., \& Murphy, D. V. (2008). Impact of Ecosystem Management on Microbial Community Level Physiological Profiles of Postmining Forest Rehabilitation. Microbial Ecology, 55, 321-332. https://doi.org/10.1007/s00248-007-9278-2

De Souza-Cruz, P. B., Freer, J., Siika-Aho, M., \& Ferraz, A. (2004). Extraction and Determination of Enzymes Produced by Ceriporiopsis subvermispora during Biopulping of Pinus taeda Wood Chips. Enzyme Microbial Technology, 34, 228-234. 
https://doi.org/10.1016/j.enzmictec.2003.10.005

Deng, S. P., \& Tabatabai, M. A. (1994). Colorimetric Determination of Reducing Sugars in Soils. Soil Biology and Biochemistry, 26, 473-477. https://doi.org/10.1016/0038-0717(94)90179-1

Franzluebbers, A. J., Hons, F. M., \& Zuberer, D. A. (1995). Soil Organic Carbon, Microbial Biomass, and Mineralizable Carbon and Nitrogen in Sorghum. Soil Science Society of America Journal, 59, 460-466. https://doi.org/10.2136/sssaj1995.03615995005900020027x

Ganzlin, P. W., Gundale, M. J., Becknell, R. E., \& Cleveland, C. C. (2016). Forest Restoration Treatments have Subtle Long-Term Effects on Soil $\mathrm{C}$ and $\mathrm{N}$ Cycling in Mixed Conifer Forests. Ecological Applications, 26, 1503-1516.

https://doi.org/10.1002/15-1100

Garcia-Montiel, D. C., Neill, C., Melillo, J., Thomas, S., Steudler, A. P., \& Cerri, C. C. (2000). Soil Phosphorus Transformations Following Forest Clearing for Pasture in the Brazilian Amazon. Soil Science Society of America Journal, 64, 1792-1804. https://doi.org/10.2136/sssaj2000.6451792x

Gardner, T., Acosta-Martinez, V., Senwo, Z., \& Dowd, S. E. (2011). Soil Rhizosphere Microbial Communities and Enzyme Activities under Organic Farming in Alabama. Diversity, 3, 308-328.

Giai, C., \& Boerner, R. E. J. (2007). Effects of Ecological Restoration on Microbial Activity, Microbial Functional Diversity, and Soil Organic Matter in Mixed-Oak Forests of Southern Ohio, USA. Applied Soil Ecology, 35, 281-290.

https://doi.org/10.1016/j.apsoil.2006.08.003

Grayston, S. J., \& Rennenberg, H. (2006). Assessing Effects of Forest Management on Microbial Community Structure in a Central European Beech Forest. Canadian Journal of Forest Research, 2604, 2595-2604. https://doi.org/10.1139/x06-154

Grogan, P., Baar, J., \& Bruns, T. D. (2000). Below-Ground Ectomycorrhizal Community Structure in a Recently Burned Bishop Pine Forest. Journal of Ecology, 88, 1051-1062. https://doi.org/10.1046/j.1365-2745.2000.00511.x

Hofrichter, M. (2002). Review: Lignin Conversion by Manganese Peroxidase (MnP). Enzyme Microbial Technology, 30, 454-466. https://doi.org/10.1016/S0141-0229(01)00528-2

Jonsson, L., Dahlberg, A., Nilsson, M.-C., Zackrisson, O., \& Kårén, O. (1999). Ectomycorrhizal Fungal Communities in Late-Successional Swedish Boreal Forests, and Their Composition Following Wildfire. Molecular Ecology, 8, 205-215.

https://doi.org/10.1046/j.1365-294x.1999.00553.x

Kelliher, F. M., Ross, D. J., Law, B. E., Baldocchi, D. D., \& Rodda, N. J. (2004). Limitations to Carbon Mineralization in Litter and Mineral Soil of Young and Old Ponderosa Pine Forests. Forest Ecology and Management, 191, 201-213.

https://doi.org/10.1016/j.foreco.2003.12.005

Kelly, C. N., Calderon, F. C., Acosta-Martınez, V., Mikha, M. M., Benjamin, J., Rutherford, D. W., \& Rostad, C. E. (2015). Switchgrass Biochar Effects on Plant Biomass and Microbial Dynamics in Two Soils from Different Regions. Pedosphere, 25, 329-342. https://doi.org/10.1016/S1002-0160(15)30001-1

Klopatek, C. C., Debano, L. F., \& Klopatek, J. M. (1988). Effects of Simulated Fire on Vesicular-Arbuscular Mycorrhizae in Pinyon-Juniper Woodland Soil. Plant Soil, 109, 245-249. https://doi.org/10.1007/BF02202090

Lucas, R. W., Casper, B. B., Jackson, J. K., \& Balser, T. C. (2007). Soil Microbial Communities and Extracellular Enzyme Activity in the New Jersey Pinelands. Soil Biology 
and Biochemistry, 39, 2508-2519. https://doi.org/10.1016/j.soilbio.2007.05.008

McRae, D. J., Duchesne, L. C., Freedman, B., Lynham, T. J., \& Woodley, S. (2001). Comparisons between Wildfire and Forest Harvesting and Their Implications in Forest Management. Environmental Review, 9, 223-260. https://doi.org/10.1139/a01-010

Nobles, M. M., Dillon, W., \& Mbila, M. (2009). Initial Response of Soil Nutrient Pools to Prescribed Burning and Thinning in a Managed Forest Ecosystem of Northern Alabama. Soil Science Society of American Journal, 73, 285-292. https://doi.org/10.2136/sssaj2007.0137

Parham, J. A., \& Deng, S. P. (2000). Detection, Quantification and Characterization of $\beta$-Glucosaminidase Activity in Soil. Soil Biology and Biochemistry, 32, 1183-1190. https://doi.org/10.1016/S0038-0717(00)00034-1

Pietikåinen, J., \& Fritze, H. (1995). Clear-Cutting and Prescribed Burning in Coniferous Forest: Comparison of Effects on Soil Fungal and Total Microbial Biomass, Respiration Activity and Nitrification. Soil Biology and Biochemistry, 27, 101-109. https://doi.org/10.1016/0038-0717(94)00125-K

Schutter, M. E., \& Dick, R. P. (2000). Comparison of Fatty Acid Methyl Ester (FAME) Methods for Characterizing Microbial Communities. Methods, 1668, 1659-1668. https://doi.org/10.2136/sssaj2000.6451659x

Šnajdr, J., Valášková, V., Merhautová, V., Herinková, J., Cajthaml, T., \& Baldrian, P. (2008). Spatial Variability of Enzyme Activities and Microbial Biomass in The Upper Layers of Quercus petraea Forest Soil. Soil Biology and Biochemistry, 40, 2068-2075. https://doi.org/10.1016/j.soilbio.2008.01.015

Tabatabai, M. A. (1994). Soil Enzymes. In R. W. Weaver, J. S. Angle, \& P. S. Botttomley (Eds.), Methods of Soil Analysis: Microbiological and Biochemical Properties (pp. 775-833). Madison, WI: Soil Science Society of America.

Tian, D.-L., Peng, Y.-Y., Yan, W.-D., Fang, X., Kang, W.-X., Wang, G.-J., \& Chen, X.-Y. (2010). Effects of Thinning and Litter Fall Removal on Fine Root Production and Soil Organic Carbon Content in Masson Pine Plantations. Pedosphere, 20, 486-493. https://doi.org/10.1016/S1002-0160(10)60038-0

Valášková, V., Šnajdr, J., Bittner, B., Cajthaml, T., Merhautová, V., Hofrichter, M., \& Baldrian, P. (2007). Production of Lignocellulose-Degrading Enzymes and Degradation of Leaf Litter by Saprotrophic Basidiomycetes Isolated from a Quercus petraea Forest. Soil Biology and Biochemistry, 39, 2651-2660. https://doi.org/10.1016/j.soilbio.2007.05.023

Wagner, H., \& Wolf, D. C. (1998). Carbon Transformation and Soil Organic Matter Formation. In D. M. Sylvia et al. (Eds.), Principles and Applications of Soil Microbiology (pp. 218-256). Upper Saddle River, NJ: Prentice-Hall.

Wander, M. (2004). Soil Organic Matter Fractions and Their Relevance to Soil Function. In F. Magdoff, \& R. Weil (Eds.), Soil Organic Matter in Sustainable Agriculture (pp. 67-102). Boca Raton, FL: CRC Press. https://doi.org/10.1201/9780203496374.ch3

Wic-Baena, Andres-Abellan, E. M., Lucas-Borja, M. E., Martinez-Garcia, E., Garcia-Morote, F. A., Rubio, E., \& Lopez-Serrano, F. R. (2013). Thinning and Recovery Effects on Soil Properties in Two Sites of a Mediterranean Forest, in Cuenca Mountain (Southeastern of Spain). Forest Ecology and Management, 308, 223-230.

https://doi.org/10.1016/j.foreco.2013.06.065

Zelles, L. (1999). Fatty Acid Patterns of Phospholipids and Lipopolysaccharides in the Characterization of Microbial Communities in Soil: A Review. Biology and Fertility of Soils, 29, 111-129. https://doi.org/10.1007/s003740050533 